\title{
EVALUATION OF THE GREEN OPEN SPACE POLICY OF BEKASI CITY IN ACHIEVING DEVELOPMENT INDICATORS (SUSTAINABLE SETTLEMENTS)
}

\author{
Najmuddin', Sucahyanto $^{2}$, Muzani Jalaluddin ${ }^{3}$ \\ ${ }^{1}$ Student Pascasarjana Manajemen Lingkungan, Universitas Negeri Jakarta, \\ (email: najmuddinunj86@gmail.com) \\ ${ }^{23}$ Lecture of Universitas Negeri Jakarta
}

\begin{abstract}
The objective of this research was to evaluate the green open space policy of Bekasi City in achieving development indicators (sustainable settlements). It was a qualitative research with evaluation method conducted in the City of Bekasi, West Java in 2018. The data were collected through participant observation using interview, observation, and document study. The data was analysed and interpretated through (1) Data reduction, sorting, concentration and simplification of "rough" data, abstracting, and information that emerge from written records in the field: (2) Display data, try to present data and the whole picture and certain parts of the research; (3) Conclusions and verification, search and find meaning for the data collected by looking for patterns of relationships, similarities, differences and the systems. The findings of the implementation have been carried out but must be revised to adapt the development of the central government, named the National Strategic Project. Green open space in the City of Bekasi will be increased every year to $0.15 \%$ in a sustainable manner so that green open space can be consistently distributed throughout the City of Bekasi.
\end{abstract}

Keywords: Evaluatin. The Green Open Space, Sustainable Settlements 


\section{INTRODUCTION}

The dynamic development of cities in Indonesia today seems to be based more on exploitation of resources. This is proven by the lack of attention in the balance of the development. The developments considerations are only oriented towards achieving profit without considering the quality of environmental capacity and the significance environmental improvements. Hence, sustainable development policy innovations are shaped because there must be initiative and commitment from government leaders, a change in mindset so that trustworthiness is constructed in managing street vendor, bureaucratic reform followed by the preparation of supporting documents, and continuous and integrated implementation mechanisms which focus on utilizing welfare. Therefore, the environmental management is required to consider the balance of the surrounding environment so that it does not cause a disaster. However, an efficient and effective arrangement provides beauty and comfort to the community life.

Accordintg BPS (2016) stated that one of the goals in the indicator (11) sustainable cities and settlements is to directly invite regional governments to play their role in realizing the Post-2015 Agenda. Indicator 11) Sustainable cities and settlements have 7 targets: (1) In 2030, guaranteeing access to basic and safe housing and basic services for all and improving conditions; (2) In 2030, providing access to a safe, affordable, accessible and sustainable transportation system for all, improving traffic safety, especially by increasing public transportation, paying special attention to the needs of vulnerable communities, women, children, persons with disabilities and the elderly; (3) In 2030, increasing inclusive and sustainable urbanization and capacity for participatory, integrated and sustainable settlement planning and management in all countries;

Strengthening efforts to protect and safeguard natural world and cultural heritage; (5) In 2030, reducing the number of deaths, victims, and reducing economic losses relative to GDP caused by disasters, including water, focusing on protecting the poor and those in vulnerable situations; (6) In 2030, reducing per capita environmental impacts in cities by paying special attention to air quality and waste management; (7) In 2030, providing universal access to green and public open spaces which are safe, inclusive, and easily accessible, especially for women and children, elderly and people with disabilities.

At the present, Bekasi City is launching green industry, but there are a few problems related to the layout about who wants to be involved in the plan. The green open space of Bekasi city is currently well organized but uncompletely finished if we look at it from the perspective of achieving Sustainable Development Goals (SDGs) since 
in reality many green open spaces (RTH) are converted into waste dumps.

Thus, the study was about the evaluation of the city's green open space policy in the framework of development (sustainable settlement) ". Fritzpatrick defines evaluation as the determination of objectives and systematics of merit (performance of intrinsic quality of objects) (Jody, 2004). Furthermore, it was stated that evaluation is a process to assess technical, administrative and procedural indicators in accordance with work processes, procedures and systems in the concerned work unit. The aim is to create commitments about what is done by the work units of government agencies to realize good governance. This means that evaluation is the process of testing certain objects or events using special value measures with the aim of determining appropriate decisions (Djudju, 2008). Then evaluation is testing the facts that occur as material for making decisions. Correspondingly, Worthen and Sanders in Sudjana described that evaluation process is a process of information to assist decision makers in choosing among available alternatives decision. In addition, evaluation is an activity to gather information about the workings of something, which is then used to determine the right alternative in making a decision. Evaluator only provides information needed by decision makers. (Krikpatrick, 2006)
According to Mazmanian and Sabatier (1983) the implementation is "to understand what actually happens after the program is enacted or formulated as the subject of policy implementation." Those events and activities occur after the authoritative public policy directives insurrance, including both the effort to administer substantive impact on people and events." From the notions of evaluation that have been stated above, it can be concluded that evaluation is a process which carried out by a person or group of people to see the extent of the success of a program implemented in an organization. Implementation is a way or form of changing decisions into applications. In other words, implementation is an effort to implement what should have been decided by the policy maker.

According to Medco foundation Green open space is an area that forming a path and / or clustered area, which used more openly, where plants grow both naturally and planted. Open green spaces are important urban assest and have important role in maintaining the health of urban ecological systems (Asian Development Bank: 2012). This means that a city without a green open space is a dead city.

According to EURO WHO Urban green space is a component of "green infrastructure". It is important part of the public open spaces and common services provided by a city and can serve as a health- 
promoting setting for all members of the urban community. Thus, plants in green open spaces provide oxygen and manage oxygen respiration. The urban green space is an important investment that local authorities can make on behalf of their citizens and their well-being. This means that urban green spaces are important investments that can be made by local authorities for citizens and their welfare. A green open space provides a comfortable feeling for residents in the city.

Grindle in Subarsono formulated that the success of implementation can be influenced by 2 (two) variables, including the following: (1) Content of policy that covers the extent to which the interests of the target group, the types of benefits received by target groups, the extent to which the desired change from a policy, whether or not the location of the program is correct, whether or not the policy has mentioned the implementor in detail, and whether or not the program is supported by adequate resources; (2) A policy environment that includes power, interests, and strategies possessed by the involved actors, the characteristics of the institution and regime in power, the level of compliance and responsiveness of the target group (Subarsono, 2010).

Policies and efforts made for a sustainable green city create conditions that can provide more valid alternatives for each citizen to achieve his/her most humanistic aspirations (Mahi and Trigunarso, 2017). The purpose of the development is to realize a nation that is advanced, independent and prosperous physically and spiritually, as the foundation for the next stage of development towards a fair and prosperous society. The sustainable city development is included in SDG's (Sustainable Development Goals). Sustainable development is an activity carried out continuously so that the continuity of activities has been carried out.

\section{METHOD}

This study aimed at evaluating the green open space policy of Bekasi city in the context of sustainable development (cities and sustainable settlements) in the Regional Regulation of Bekasi City Number 13 year of 2011 Bekasi City Spatial Planning for 20112031. This research was conducted in Bekasi City, West Java Province, to obtain data on information on Bekasi City Regulation Number 13 of 2011 Bekasi City Spatial Planning for 2011-2031, interviews and focus group discussions were conducted. The procedure of this study was carried out by interview, observation and focus group discussion. The method used was descriptive research about policy evaluation with content analysis techniques.

\section{RESULTS AND DISCUSSION}

Green open space (RTH) is an elongated lane and / or clustered area, which is used more openly, where plants grow, both 
naturally grown and planted. Green open spaces in Bekasi city include green park open spaces, green open spaces of urban forests, green open spaces and pathways and there are also public green open spaces and private green open spaces.

The implementation of a green open space policy in Bekasi city has developed a deviation of $26.07 \%$, even though in regional regulation Number 17 year of 2011, the space utilization permits have been regulated that the development of any sector must provide around $15-20 \%$ of green land to be built.

In making policies to support the development of green open spaces, the economic aspect is a dominant consideration compared to environmental and social aspects. This happened at Bekasi city with a large number of malls which mostly deviate, not for green open spaces but preoccupied as visitor parking spaces. Another difficult thing is the lack of available land and the soaring land prices, so it needs a large budget. Procurement of land for public green open spaces such as urban forests and urban parks must consider the land prices which tend to increase every year. Therefore the government manages it through corporate social responsibility (CSR).

The implementation of a green open space management policy is always there with the aim of arranging public green open spaces to meet $0.15 \%$ according to the City of Bekasi. Local government strategies in managing or building green open spaces are monitoring the establishment of new buildings, establishing the plans area of Bekasi city that should not be built, building green land using CSR funds, compiling green city policies and empowering green communities. The problem is that there are often deviations in the development, so that the local government itself must try to build green open space by utilizing funds from CSR. Thus, for this reason, the regional government must immediately implement the strategy. The development of green open space in the Bekasi City area is very little for the regional government to follow the operational guidelines for spatial utilization.

Green open space management is as a strategic area for maintaining environmental preservation because in Bekasi City, part of Jabodetabek is meant as one of the areas which land is higher than DKI Jakarta where Bekasi City must maintain its environment so that environmental problems do not occur. Since its part is close to DKI Jakarta, the regulations regarding the development of Bekasi city are often revised in accordance to the development of DKI Jakarta, in this case the making of LRT.

The spatial planning of Bekasi city through the RTRWK aims to realize Bekasi city as a comfortable shelter and creative business with stedily improved the quality of life. Bekasi city has spatial planning related to DKI Jakarta, integrated use of space and 
utilization control Bekasi City Area is regulated in Law Number 26 year of 2007 concerning National Spatial Planning, Presidential Regulation Number 54 year of 2008 concerning Arrangement of Jakarta, Bogor, Depok, Tangerang, Bekasi, Puncak Cianjur Regions, and Government Regulation Number 15 year of 2010 concerning Spatial Planning Implementation. Meanwhile, Bekasi City Government issued "Bekasi City Regional Regulation Number 13 year of 2011 concerning the Bekasi City Spatial Plan for 2011-2031". Based on the results of the regional regulation research, there are rules regarding green open spaces that function as conservation areas for hydrological preservation, areas for mitigation or evacuation of natural disasters, ecology, water absorbing areas, areas for creating microclimates and reducing pollutants in Bekasi City, recreational and sports areas community, limiting the development of the city in an unexpected direction, safeguarding data sources both artificial and historical, providing green open space that is private in nature, through limiting density and utilization criteria, increasing comfort, beautifying the environment, creating a harmonious and balanced atmosphere between the built area and not awakened. Green open space in Bekasi City covers 189 $\mathrm{m} 2$ and green open space $\&$ water polder area is $317 \mathrm{~m} 2$, so the total area is $506 \mathrm{~m} 2$, but it is not sufficient for that Bekasi city government plans to increase the green open space as much as $0.15 \%$.

Bekasi City area is flowed by the Cakung River, Bekasi River and Sunter River, along with its tributaries, so around each river flows around Bekasi City government plants trees, and makes artificial green open spaces so that river water can be controlled. Based on the Bekasi City Regional Regulation Number 13 year of 2011 concerning Bekasi City Spatial Planning in 2011-2031, a 30\% green open space area is needed so that the impact of controlling environmental problems will occur.

The regulation on the improvement of use efficiently, effectively and harmonious space within the earth by paying attention to local wisdom and in accordance to statutory provisions. The regulation refers to Law Number 26 year of 2007 concerning Spatial Planning in the Province and District / City and has the function of assisting in the implementation of the duties of Governors and Regents / Mayors in spatial coordination in the regions.

Based on interviews with Bekasi City government officials, Bekasi City Regulation Number 13 of 2011 concerning the Bekasi City Spatial Plan for 2011-2031, does not regulate outside areas but along with the development of the Capital City's National Strategic Project, the blueprint of layout Bekasi City must be reviewed. 
The implementation of the Bekasi City spatial layout in the green open space is referred to the Bekasi City Regional Regulation Number 13 of 2011 concerning the Bekasi City Spatial Plan for 2011-2031. Up to the District level, where each SubDistrict Head is a Regional Work Unit (SKPD) or the smallest unit of the regional government of Bekasi City, as the implementation of regional regulations. The smaller unit is the head of a village (RT), whose duties are directly related to the local community. The authority of the sub-district head (camat) does not regulate the village; it is only coordination of work. As long as the activities in kelurahan do not deviate from the existing rules, sub-district head should not intervene, especially in the matter of buying and selling land.

Physical and social impacts in Bekasi City from the implementation of the Bekasi City Regional Regulation Number 13 year of 2011 concerning the Bekasi City Spatial Plan for 2011-2031 where green open spaces are included. Authorization to build a new building must be in accordance with the rules; there will be a demolition and sealing because the deviation of the building permit in Bekasi City is $26.07 \%$. The construction of green open space must be equipped with facilities and infrastructure in Bekasi city to be more improved for the welfare of the community, so it will not damage the natural environment.
Selling and purchasing land owned by residents deal directly with the head of the village. Transfer land ownership does not violate the rules, because of personal rights, includes if buyers from outside the area. The sub-district head as the Land Deed Making Officer (PPAT) represents the Regional Government National Land Agency (BPN Pemda). Sub-district head does not have the authority to prohibit citizens from buying and selling land in Bekasi City.

New owners who are not native, generally renovating old houses become better buildings. In such cases, if the design does not deviate, then it is not disputed. When calculated from the use of environmental facilities (eg groundwater, sanitation, land cover, etc.), these new buildings will need more natural resources in the environment. In fact, there is a lot of land ownership in Bekasi City which results in reduced natural resources so that the local government of Bekasi City plans every year that green open space will increase by $0.015 \%$ to minimize regional space patterns by $14 \%$.

Another problem that has been faced in implementing Bekasi City Regional Regulation Number 13 year of 2011 concerning Bekasi City Spatial Planning for 2011-2031 is the use of land or land irregularities that are not in accordance with its design, but its existence long before the Regional Regulation was made. Ownership or building designs that are not suitable is 
"legally valid". Although in terms of the environment it is not appropriate for the buildings to be constructed.

The information on population growth in the Bekasi city in 2018 is part of the nonnative population of Bekasi City but residents of other regions due to the construction of National Housing (Perumnas) II and II in East Bekasi and other housing. There are 40 more housing with a development area of 800 hectares in Bekasi city. The development of this property will be followed by the operation of the Jakarta-Cikampek Toll Road which facilitates transportation and economic access.

Socio-economic achievement in Bekasi City, The Rate of Economic Growth $(L P E)$ in the city of Bekasi for four years tends to move dynamically. $L P E$ is one indicator of the success of development from an efficiency aspect initiated by the government. The higher the LPE, the better there will be improvements in development in the regional economic sectors. The average value of LPE in Bekasi City penetrated 5.82\% from 2013 to 2016. The high and low LPE of an economy is determined by the real Gross Regional Domestic Product $(P D R B)$ of the region in the same period of time by breaking $5.53 \%$. Based on the data obtained, Bekasi city $L P E$ in 2013 reached 6.04\%; 2014 and 2015 decreased to $5.61 \%$ and $5.57 \%$. Then in 2016 it rose again to 5.82\%. Bekasi city GRDP in 2016 has nominally broken the Rp.
58.82 trillion figures. In fact, the $L P E$ of Bekasi City was $6.08 \%$ in 2016, higher than the $L P E$ of West Java Province with an achievement of $5.67 \%$.

Bekasi city has managed three rivers: Cakung, Bekasi and Sunter River Watersheds. The watershed is divided into upstream, middle and downstream areas. Biogeophysically, the upstream area of the watershed is characterized as a conservation area which has a higher drainage density, an area with a large slope, not a flood area, regulates the use of water drainage patterns and the type of vegetation is generally a forest stand. Whereas the downstream watershed is characterized as a smaller drainage density, a small to very small slope area, in some places, it is a flood area, the regulation of water use is determined by irrigation buildings, the vegetation type is dominated by agricultural crops except the estuary area dominated by mangrove / peat forest. The management of watersheds in Bekasi city must be handled thoroughly from upstream to downstream and cannot be submitted to each administrative area. The management must be based on watershad management, in the form of one river one management, namely one river managed by one of the special bodies that has the authority to regulate from upstream to downstream, based on environmental, physical and social factors of the area.

The policy basis contains in the 16 articles of the Bekasi City Regional 
Regulation Number 13 year of 2011 concerning the Bekasi City Spatial Plan for 2011-2031 with the study of the green open space policy which is not functioning properly due to irregularities. Therefore, it is expected that villages (RT RW) in Bekasi city has the ability to maintain and reverse the function of green open space in accordance with applicable laws.

Strong commitment is needed from Bekasi city authorities to run the Bekasi City Regional Regulation Number 13 year of 2011 concerning the Bekasi City Spatial Plan for 2011-2031 because there are still inconsistencies in land use. Coordination between institutions both inside and outside of Bekasi City government is needed.

\section{CONCLUSION}

Based on the results of the research and discussion, it is concluded as follows:

1. The implementation of Bekasi City Regulation No. 13 year of 2011 concerning the Bekasi City Spatial Plan for 2011-2031 has been implemented but still needs to be reviewed with the centeral government, which is a national strategic project.

2. The results of the evaluation of the application of the Bekasi City Regional Regulation of Bekasi City No. 13 year of 2011 concerning the Bekasi City Spatial Plan for 2011-
2031 in Bekasi city is a deviation of $26.07 \%$. This is due to the lack of coordination between the Bekasi City Government and each District.

3. The Basic policies contained in the 16 articles of the Bekasi City Regional Regulation Number 13 year of 2011 concerning Bekasi City Spatial Planning for 2011-2031 with the study of green open space policies do not functioning properly due to irregularities. Thus, it is expected that villages in Bekasi city has the ability to maintain and reverse the function of green open space in accordance with the applicable laws.

The evaluation which are resulted from the application of Bekasi City Regional Regulation of Bekasi City No. 13 year of 2011 concerning the Bekasi City Spatial Plan for 2011-2031 in Bekasi City that there is the lack of green open spaces, therefore the Bekasi City Government will increase green open space to $0.15 \%$.

\section{REFERENCES}

AG, Subarsono. 2010. Analisis Kebijakan Publik Konsep Teori dan Aplikasi. Yogyakarta: Pustaka Pelajar.

Asian Development Bank. 2012. Green Cities. Philippines: Asian Development Bank. 
Byrch Christine, Kearins Kate, 2009. Research Business Review. Sustainable Development: What Does it Really Mean? The University of Auckland Business School: The University of Auckland.

Carl J. Friedrich, 1963. Man and His Government (New York: McGraw Hill.

Daniel L. Mazmanian and Paul A. Sabatier, 1983. Implementation and Public Policy, New York: Harperolins.

Djudju Sudjana, 2008. Evaluasi Program Pendidikan Luar Sekolah. Bandung: Remaja Rosda Karya.

Eko Budihardjo dan Djoko Sujarto, 2013. Kota Berkelanjutan (Sustainable City). Bandung: Alumni.

Harold D. Lasswell and Abraham Kaplan, 1968. Power and Society New Haven: Yale University Press.
Jody L. Fitzpatrick, et all, 2004. Program Evaluation: Alternative Approach and Practical Guidelines, $3^{\text {rd }}$ Edition. Boston: Pearson Education, Inc.

Krikpatrick. 2006. Measurement in Education. New Jersey: EnglewoodClifs Prentice Hall.

Prof. Dr. Ir. Ali Kabul Mahi, M.S dan Dr. Sri Indra Trigunarso, S.K.M., M.Kes. 2017. Perencanaan Pembangunan Daerah: Teori dan Aplikasi. Depok: Kencana.

Riant Nugroho D. 2011. Public Policy: Dinamika Kebijakan-Analisis Kebijakan-Manajemen Kebijakan. Jakarta: Elek Media Kamputundo.

http://www.medcofoundation.org/mengenalruang-terbuka-hijau (15 Februari 2018, 19:00 wib)

http://www.euro.who.int/_data/assets/pdf_fil e/0010/342289/Urban-GreenSpaces_EN_WHO_web.pdf September 2018, 13:30 wib) 